\title{
The Leadership Contribution towards Pleasure Member of Kelompok Tani in Malang Regency East Java
}

\author{
Ugik Romadi, Hamyana, Suryaman Sule \\ Politeknik Pembangunan Pertanian Malang, Malang, India \\ Email: ugikromadi13@gmail.com
}

How to cite this paper: Romadi, U., Hamyana and Sule, S. (2018) The Leadership Contribution towards Pleasure Member of Kelompok Tani in Malang Regency East Java. Open Journal of Social Sciences, 6, 331-339.

https://doi.org/10.4236/jss.2018.612028

Received: November 27, 2018

Accepted: December 26, 2018

Published: December 29, 2018

Copyright (c) 2018 by authors and Scientific Research Publishing Inc. This work is licensed under the Creative Commons Attribution International License (CC BY 4.0).

http://creativecommons.org/licenses/by/4.0/

\begin{abstract}
This research specifically aims to know and analyze the value of direct contribution of leadership to the pleasure MEMBER OF KELOMPOK TANI in Malang Regency East Java Province. The method of this research is survey method. The location of the research was conducted on Kelompok Tani that was targeted by the UPSUS of Increasing Production of Paddy, Corn and Soybeans in 2017. Research Objects are Farmers who become group leaders and group members who are members of farmer groups who receive assistance UPSUS program to Increasing Production Rice, Corn and Soybean. The results showed that the direct effect of leadership variables on member satisfaction has a significance value greater than $0.05(0.210)$, which means no significant effect. The results showed that the direct effect of leadership variables on member satisfaction has a significance value greater than 0.05 (0.210), which means no significant effect. While the standardized value of beta coefficient on $t$ test shows that the magnitude of direct influence of leadership on member satisfaction is equal to 0.115 or rounded to $11 \%$. That is, the high level of member satisfaction can only be influenced by the leadership of $11 \%$ while the rest $(89 \%)$ influenced by other factors outside the model.
\end{abstract}

\section{Keywords}

The Leadership Contribution, Pleasure Member of Kelompok Tani

\section{Introduction}

The challenge of agricultural development is increasingly severe. The implementation of ASEAN economic community will directly or indirectly affect the agricultural sector. The main demands to be met by farmers in order to survive 
in an era of free market this vortex is competitiveness. It is impossible to be able to compete and be able to be a winner if the competitiveness of the nation's owned by farmers is still low. To be able to improve the competitiveness of both the nature of capacity and capability, one of requirements that must be developed is a qualified farmer institution in carrying out its main duties and functions. Logically, to be able to fight and survive in this era of intense competition, one cannot be if only relies on the ability alone. It requires a systematically organized mix of potential to compete and win all these free market challenges. Besides this, the conducive climate bureaucracy as a supporting factor is no less important.

Institutional farmer groups are activities that are used to gather various strengths possessed by all elements. The perspective of development sociology describes the institutional as the organs within the human body that activate the society. Every function in society must be run by an (or more) institutional. To meet needs, for example: in terms of production and distribution, it is operated by economic institutions. Everyone involved in it is bounded by a pattern of values and norms as a guide to behave and behave in social interaction, which is established later by the existence of a standard structure, which is the visualization of who is involved, position and proportionality.

Unfortunately the conditions of the farmers' institutions, especially the farmer groups, have not yet been able to fulfill their expectations. The development of farmer institutions in rural areas in reality has not yet had a good impact. There are some reasons of things that cause the failure of farmer institutions in the countryside (Zuraida dan Rizal, 1993; Agustian, dkk., 2003; Syahyuti, 2003; Purwanto, dkk., 2007): [1] farmer groups are generally formed based on technical interests to facilitate coordination if there are government activities or programs, so that they are more program oriented, and do not guarantee group independence and group sustainability, [2] participation and cohesiveness of group members in group activities are still relatively low, [3] management of productive activities of group members still individual, [4] the establishment and development of institutions does not use the basis of local social capital with the principle of local independence, which is achieved through economic principles and empowerment, [5] establishment and institutional development based on blue print approach, [6] establishment and institutional development based on a top down approach, [7] institutions that are built are limited to strengthening horizontal bonds, not vertical ties, [8] even though the institution has been formed, but the guidance that is carried out tends to be individual, namely only to the management, [9] institutional development always uses structural paths, and is weak from the development of its cultural aspects.

Meanwhile, the institutional challenges faced by farmers particularly farmers' groups are: [1] the demands of the development of institutional capacity, [2] support of government and society, [3] government policies, [4] the legal basis and the status of farmer groups, [5] demands of science and technology progress, [6] community values and expectations and [7] globalization demands. Responding to the problems and challenges encountered above, it shows that 
farmer groups need to make efforts to improve their capacity and quality so as to compete and contribute in the process of agricultural development. Optimizing the utilization of inputs owned Kelompok Tani is a logical option that can be done. The inputs of the farmer group are: [1] the vision, mission, goals and objectives of the farmers group; [2] manpower; [3] group members; [4] legal basis and status of farmer group [5] facilities and infrastructure; [6] financing; [7] ADART; [8] organization; [9] administration; [10] Organizational Culture. In order to optimize this input, it obviously requires a good managerial and systematic process. In management activities, it will be able to realize all the resources for all the problems and challenges that are opposite. To describe how the management process development in order to face the challenges to be faced in the future, it would require an investigation that is able to measure the level of satisfaction of members using variables of leadership, group performance, and organizational culture, to the satisfaction of members who will be feedback to management development Kelompok Tani in improving the quality and capacity of the group to compete with the other party. Based on the background of the research mentioned above, the limitation of this research problem is how much contribution of leadership to Member pleasure. Besides, the specific goals to be achieved in this research are to determine and analyze the value of a direct contribution to the leadership of Member pleasure.

\section{Method}

This research method uses survey method. Survey research in question is to explain the causal relationship with hypothesis testing. As stated by Singarimbun, Masri dan Sofian Effendi (2008) survey research can be used for the purpose of: [1] explorative [2] descriptive; [3] explanatory (explanatory or confirmatory); [4] evaluation; [5] predict or predict certain events in the future; [6] operational research; [7] development of social indicators. The study developed in this research was conducted by literature study and field study. The Data collection techniques use questionnaires.

The location of the research was conducted on farmer groups that were targeted by the UPSUS to Increasing Production of Paddy, Corn and Soybeans in 2017 in Malang. Research Objects are Farmers who become group leaders and group members who are members of a group of beneficiaries grant program Increased Rice Production Increasing Paddy, Corn and Soybean in 2017. Determination of respondents conducted randomly on the population of research objects. The number of samples chosen by random sampling is 100 people. Data analysis techniques used are descriptive analysis and multiple linear regression analysis.

The data analysis technique used is multi analysis including descriptive analysis, multiple linear regression analysis and path analysis. Specifically path analysis will be used in testing the magnitude of the contribution shown by the path coefficients on each path diagram and causal relationships between variables. 


\section{Results and Discussions}

\subsection{Test Validity and Reliability Instruments}

\subsubsection{Validity Test}

Validity test was performed using bivariate correlation analysis between each score indicator with total score of construct, analytical using IBM SPSS 20 software. Based on the output of SPSS analysis, it can be concluded that the correlation between each indicator of both leadership variables (X1), and Member pleasure (X2) indicates a significant correlation level of 0.01 to the total score of leadership variable X1 and Member Satisfaction X4. Thus it can be concluded that each indicator of constructs/variables is valid.

\subsubsection{Test Reliability}

Based on the results of SPSS analysis shows that leadership construct (X1) gives a value of Cornbach Alpha ( $\alpha$ ) 0.930 or $93 \%$ which according to Nunnally (1994) criteria can be categorized reliable because $>0.70 \%$ or $70 \%$. Member pleasure (X2) of each value of Cornbach Alpha ( $\alpha$ ) $0.897 \%$ or $89.7 \%$ and $0.944 \%$ or $94.4 \%$ which according to Nunnally (1994) criteria can also be categorized as reliably $>0.70 \%$ or $70 \%$.

\subsection{Prerequisite Analysis}

\subsubsection{Linearity Test}

Linearity test aims to determine whether the two variables have a linear relationship or not significantly. This test is usually used as a prerequisite in correlation analysis or linear regression. The tools used in the linearity test using IBM SPSS 20 software by ANOVA (F test). There are two results that we need to look at first is the column F-linearity and column F-DEVIATION FROM linearity. F-Linearity shows the extent if the dependent variable is predicted to lie exactly in a straight line. If the result is significant $(p<0.05)$ then a suitable linear model is applied to the model relationship. When the F-DEVIATION FROM LINEARITY shows that more significant the value of $\mathrm{F}$, then the greater the case deviation. If we find $p>0.05$ in the column deviation from linearity then our data can be said to be linearly related. In other words, the two variables is said to have a linear relationship when the F-Linearity significant $(p<0.05)$; and F Deviation from Linearity is in the insignificant range ( $p>0.05)$. The following is the result of linearity test output on each model of regression equation.

The SPSS output shows that the relationship between Leadership variable to the Member pleasure variable has met the linear assumption since F Deviation from Linearity is in the insignificant range $(\mathrm{F}=1.137 ; \mathrm{p}>0.05)$. Additional information indicates that the linearity assumption is strong enough because the $\mathrm{F}$-linearity is in the significant range $(\mathrm{F}=79.284 ; \mathrm{p}<0.05)$. As well as organizational performance variable to variable Member satisfaction has met the linear assumption for $\mathrm{F}$ Deviation from Linearity is in the range not significant $(\mathrm{F}=$ 1.516; $\mathrm{p}>0.05$ ). Additional information indicates that the linearity assumption 
is strong enough because the F-linearity is in the significant range $(\mathrm{F}=15.667 ; \mathrm{p}$ $<0.05)$. SPSS calculation results on the linearity of the variable of organizational culture on satisfaction of members also have to meet the assumptions of linear because $F$ Deviation from Linearity is in the range not significant $(F=0.149 ; p>$ $0.05)$. Additional information indicates that the linearity assumption is strong enough because the $\mathrm{F}$-linearity is in the significant range $(\mathrm{F}=82.849 ; \mathrm{p}<0.05)$

\subsubsection{Multicollinearity Test}

The Multicolinearity test is performed to see if there is any relationship between the relationship between the independent variables. To find out the test results from multicollinearity test can be seen from several ways, namely as follows:

1) By looking at the tolerance values:

- If the tolerance value itself is greater than 0.10 then it can be concluded that there is no multicollinearity

- While the nila tilapia tolerancenya smaller than 0.10 then the conclusion is multicollinearity.

2) By looking at the VIF value:

- If the VIF value is more than 10 , then we will get the conclusion that the data we tested has multicollinearity

- Whereas if the VIF value is below 10 , then we will get the conclusion that the data we tested has no collinierity.

Based on the result of SPSS output above, it can be concluded that the tolerance value of independent variable on the regression equation, greater than 0.10 ; and its VIF value is less than 10.00. Thus there is no multicollinearity.

\subsubsection{Normality Test}

In testing the normality of data, common method, one of which is the Kolmogorov-Smirnov test. The basis of the decision is based on the probability that if the probability value is $>0.05$ then Ho is accepted (the population is normally distributed); and if the probability value $<0.05$ then Ho is rejected (the population is not normally distributed).

Based on the result of SPSS output above, it can be concluded that Kolmogorov-Smirnov $Z$ value of Unstandardized Residual variable in each regression equation is 0.695 , (greater than 0.05 ). Thus, Ho is accepted (normally distributed population).

\subsubsection{Autocorrelation Test}

The autocorrelation test aims to test whether in the regression equation is built there is a correlation between the confounding error in period $t$ with the intruder error in period t-1 (previous). In determining the occurrence of an autocorrelation or not a regression equation using Durbin-Watson (D-W) test refers to the following provisions:

- If the D-W value is less than the lower limit $(\mathrm{dL})$ or greater than $(4-\mathrm{dL})$ means that there is an autocorrelation

- If the $\mathrm{D}-\mathrm{W}$ value lies between the upper limit value (dU) and (4-dU) means 
no autocorrelation occurs

- If the D-W value lies between dL and dU, or (4-dL) and (4-dU), it does not produce a definite conclusion.

Here are the results SPSS output on the regression equation built: SPSS analysis results mentioned above, it can be interpreted that the value of DW in Equation (3) is 1.814 , while the upper limit value (dU) at 0.05 by the number of respondents 100 and the independent variable $(\mathrm{k}) 3$ is 1.74 . When compared to the value of the D-W (1.814) is greater than the value of $\mathrm{dU}(1.74)$ and less than $(4-$ $1.74=2.26$ ). Thus, the conclusion is no autocorrelation in the Equation (3).

\subsection{The Results of Multiple Linear Regression Analysis}

To analyze the relationship between variables as described in the research hypothesis required Member pleasure regression equation $(\mathrm{X} 2)=\mathrm{b} 1$ Leadership (X1) $+\mathrm{b} 2$. The following are the results of multiple linear regression analysis using software tools IBM SPSS 20 in the equation as shown in Table 1, Table 2, and Table 3.

Based on SPSS output can be interpreted that simultaneously, the effect of X1 to $\mathrm{X} 2$ is equal to 0.846 (rounded $85 \%$ ). The remaining $15 \%$ influence of other factors is outside the model. The model simultaneously has been significant. Having regard to the probability F of 70.477 on sig $0.000<0.01$. Once the model has proved significant simultaneous, then the path partial effect.

Table 1. Model Summary

\begin{tabular}{ccccc}
\hline Model & $\mathrm{R}$ & R Square & Adjusted R Square & Std. Error of the Estimate \\
\hline 1 &, $920^{\mathrm{a}}$ &, 846 &, 842 & 3,698 \\
\hline a. Predictors: (Constant), BO, K, KK, b. Dependent Variable: KA.
\end{tabular}

Table 2. ANOVA ${ }^{\mathrm{a}}$.

\begin{tabular}{|c|c|c|c|c|c|c|}
\hline & Model & Sum of Squares & $\mathrm{df}$ & Mean Square & $\mathrm{F}$ & Sig. \\
\hline \multirow{3}{*}{1} & Regression & $7,234,341$ & 3 & $2,411,447$ & 176,353 &, $000^{\mathrm{b}}$ \\
\hline & Residual & $1,312,699$ & 96 & 13,674 & & \\
\hline & Total & $8,547,040$ & 99 & & & \\
\hline
\end{tabular}

a. Dependent Variable: KA, b. Predictors: (Constant), BO, K, KO.

Table 3. Coefficients ${ }^{\mathrm{a}}$.

\begin{tabular}{|c|c|c|c|c|c|c|}
\hline & \multirow{2}{*}{ Model } & \multicolumn{2}{|c|}{ Unstandardized Coefficients } & \multirow{2}{*}{$\begin{array}{c}\text { Standardized } \\
\text { Coefficients }\end{array}$} & \multirow[t]{2}{*}{$\mathrm{t}$} & \multirow{2}{*}{ Sig. } \\
\hline & & $\mathrm{B}$ & Std. Error & & & \\
\hline \multirow{4}{*}{1} & (Constant) & 9,762 & 3,101 & & 3,148 &, 002 \\
\hline & $\mathrm{K}$ &, 116 & ,092 & ,115 & 1,261 &, 210 \\
\hline & $\mathrm{KO}$ & ,472 & ,073 & ,625 & 6,476 &, 000 \\
\hline & $\mathrm{BO}$ & ,326 & ,095 & ,227 & 3,424 &, 001 \\
\hline
\end{tabular}

a. Dependent Variable: KA. 
The Direct leadership not significant gives positive effect on member pleasure. The magnitude of the direct influence of leadership to satisfaction of members amounted to 0.115 or rounded to $11 \%$. That is, the level of member satisfaction is only able to be influenced by the leadership of $11 \%$ while the remaining $89 \%$ influenced by other factors outside the model.

\subsection{Direct Leadership Influence on Member Satisfaction}

Based on the results of statistical calculations, that the direct effect of leadership on member satisfaction variables have a significance value greater than 0.05 (0.210), this means that no significant effect. While the value of the standard by coefficient beta t test showed the amount of direct influence on the leadership of member satisfaction amounted to 0.115 or rounded to $11 \%$. That is, the level of member satisfaction is only able to be influenced by the leadership of $11 \%$ while the rest (89\%) influenced by other factors outside the model.

Interpretation of the results of the statistical calculations that the leadership of the group of farmers who were targeted program UPSUS rice, corn, soybeans in Malang district did not significantly affect the satisfaction of members. The results of this research differ from previous research conducted which states that the leadership has a significant effect on employee satisfaction. Leadership indicators in the form of personal integrity, proactive, the ability to mobilize resources, the ability to optimize the elements of management is not absolutely the main criterion to be considered by the members of the farmer group in determining the pattern of leadership of the organization.

The results of a survey of 100 members and administrators Kelompok Tani defined as a sample of this study showed that $1(1 \%)$ do not agree that the group leader who has integrity, Proactive, capable of mobilizing resources, and is able to optimize the management elements will create a pattern of leadership ideal; 15 people (15\%) doubted that the group leader who has integrity, Proactive, capable of mobilizing resources, and is able to optimize the management elements will create an ideal pattern of leadership; 73 people (73\%) agreed that the group leader who has integrity, Proactive, capable of mobilizing resources, and is able to optimize the management elements will create an ideal pattern of leadership; 11 people (11\%) strongly agree that the head of the group who have integrity, Proactive, capable of mobilizing resources, and is able to optimize the management elements will create an ideal pattern of leadership.

But in the context of this study, the ideal leadership is not directly proportional to the pleasure of members. As the result of statistical calculation, only $11 \%$ contribute to the leadership of member pleasure. This picture is very unique, but if we keep that reality in the lives of farmers showed emotional bond formed in the institutional structure in the wake of sometimes more dominant than structural bonding that is objective. This can be understood when viewed based on patriarchal perspective where the figure, character, and family ties are very strong in choosing a leader. The opinion of Bennis and Nanus (1995) is that a 
good leader must have personal integrity, proaktive, able to mobilize all resources, and be able to optimize the elements of management becomes irrefutable in the context of patriarchal farmers reality. According with this research that leadership has no significant effect on the satisfaction of members because the object of research (farmers target UPSUS rice, corn, soybean) still adheres patriarchy system where the pattern of interaction in institutional development that is built still emphasizes familial ties, figures and characteristic. To generate a higher level of confidence it is necessary to undertake further studies in exploring more deeply how the members of the farmers group interpret the organizations they follow. There is little difference in the behavior of members of the group as part of an informal organization with employee behavior that is a formal organization. This difference could be seen in the pattern of work is built, as well as working relationships are created. If in the informal group, the employment relationship is not based on structural or strata ties but rather family ties, while the company is on the systematic relationship based on specialization and organizational structure.

\section{Conclusions}

Based on the SPSS output above, it can be interpreted that leadership simultaneously (X1) has a positive and significant effect on organizational performance (X2). The magnitude of simultaneous influence is 0.799 or rounded up to $80 \%$, which is a contribution from the leadership variable on Organizational Performance, while the remaining $20 \%$ is influenced by other factors outside the model.

The direct contribution of leadership to member pleasures variables is positive effect but not significantly, amounting to 0.115 or rounded to $11 \%$. That is, the level of member pleasure is only able to be influenced by the leadership of $11 \%$ while the remaining $89 \%$ influenced by other factors outside the model.

\section{Conflicts of Interest}

The authors declare no conflicts of interest regarding the publication of this paper.

\section{References}

[1] Agustian, A., Supena, F., Syahyuti and dan Ariningsih, E. (2003) Studi Baseline Program PHT Perkebunan Rakyat Lada di Bangka Belitung dan Lampung (Laporan Penelitian). Pusat Penelitian dan Pengembangan Sosial Ekonomi Pertanian.

[2] Bennis, W. and Nanus (1995) Leaders: The Strategies for Taking Charge.

[3] Nunnally, J.C. and Bernstein, I.H. (1994) The Assessment of Reliability. Psychometric Theory, 3, 248-292.

[4] Olobatuyi, M.E. (2006) A User's Guide to Path Analysis. University Press of America, Lanham.

[5] Purwanta (2007) Instrumen penelitian sosial dan pendidikan. Pustaka Pelajar. Yogyakarta.

[6] Singarimbun, Masri dan Sofian Effendi, Metode Penelitian Survei, Jakarta: LP3ES, 2008 . 
[7] Syahyuti (2003) Bedah Konsep Kelembagaan: Strategi Pengembangan dan Penerapannya dalam Penelitian Pertanian. Pusat Penelitian dan Pengembangan Sosial Ekonomi Pertanian, Bogor.

[8] (2007) Strategi dan Tantangan dalam Pengembangan Gabungan Kelompoktani (GAPOKTAN) sebagai Kelembagaan Ekonomi di Pedesaan. Pusat Analisis Sosial Ekonomi dan Kebijakan Pertanian, Bogor.

[9] (2008) Petani dan Organisasi Petgani dalam Pengaruh Negara dan Pasar. Pusat Analisis Sosial Ekonomi dan Kebijakan Pertanian, Bogor.

[10] Zuraida, D. dan J. R. (Ed.) (1993) Masyarakat dan Manusia dalam Pembangunan: Pokok-Pokok Pemikiran Selo Soemardjan. Pustaka Sinar Harapan, Jakarta. 